\title{
On Liberty on Listening: John Stuart Mill and the limits of liberal responsiveness
}

Susan Bickford begins her book The Dissonance of Democracy by discussing an episode in Plato's Republic that highlights the simultaneous importance and marginality of 'listening' in the western political tradition. Polemarchus 'playfully threatens to use force' in order to compel Socrates to accompany him to the Piraeus, to which Socrates responds by suggesting he might in turn persuade Polemarchus to leave him alone. In his turn, Polemarchus asks, "“Could you persuade us...if we refused to listen?"' Bickford notes that the passage seems to hinge on the relationship between force, persuasion and listening, but that Plato does not pay much attention to the latter, an oversight reproduced by most if not all subsequent political theorists. 'Two questions come to mind,' writes Bickford (1996, p. 1), 'why is listening absent in this way?' and 'why is listening important?' She states that her concern is with the latter question; mine, however, is with the former. In this essay I will argue that liberal free speech theory, and the central importance it has assumed in twentieth and twenty-first century democratic theory and public discourse, is both a symptom and one of the causes of this obfuscation and attenuation of the importance of reception and response in both political and cultural thought. To this end, I will return to John Stuart Mill's 'classic' argument for freedom of expression in On Liberty (1859 [2011]) in order to conduct a critique of liberal free speech discourse's repetition of the scenario discussed by Bickford, which opens up possibilities for thinking about the ethics and politics of responsiveness that go beyond liberalism.

Mill's famous second chapter of On Liberty is entitled 'Of the Liberty of Thought and Discussion'. This emphasis on 'discussion' presupposes an emphasis on 
listening, receptivity and responsiveness even though he does not actually use the phrase 'thought and discussion' when he goes on to outline his arguments for liberty in the introduction. Instead, Mill (1859 [2011], p.18) uses the phrases 'liberty of conscience...thought and feeling...freedom of opinion and sentiments,' and 'liberty of expressing and publishing opinions'. This recusal of 'discussion' proves to be highly significant, as we shall see. Nevertheless, it is true that there are many passages in On Liberty where Mill does suggest that 'receptivity' to other points of view and arguments is absolutely fundamental to his argument. 'In the case of any person whose judgment is really deserving of confidence, how has it become so?' he asks rhetorically, to which he responds,

Because it has been his practice to listen to all that could be said against him...Because he has felt that the only way in which a human being can make some approach to knowing the whole of a subject, is by hearing what can be said about it by persons of every variety of opinion. (p. 27)

Furthermore, the arguments advanced in support of freedom of thought and discussion - the 'infallibility' argument; the need to test one's opinions against dissenting arguments; the argument that no single position can encompass the whole truth, and its corollary, that many opinions can hold a portion of the truth - each rely on giving all opinions a 'hearing' no matter how morally objectionable or apparently absurd because, 'we have neglected nothing that could give the truth a chance of reaching us...if the lists were kept open'. (p. 27)

For Mill, therefore, the idea of 'absolute liberty' of thought, opinion and expression is closely tied to this trope of infinite and perpetual openness, which is the enabling ground on which the receptivity to all other opinions can be rooted. 
Together, the fertile soil of unceasing argument and a 'liberal and large-minded' attitude of receptivity to other opinions nurture and nourish the progressive moral development of humankind. However, the effectivity of Mill's arguments about the benefits of openness rest on a very particular notion of 'thought' that enables an individual both potentially to think all possible thoughts and, in testing these against all possible refutations and counter-arguments, to listen and respond to all possible ideas. Repeatedly, Mill insists on the inherent virtue of what de Tocqueville called the 'antagonism of opinions' (p. xxvii) and, in a significant passage, tries to justify this by suggesting that:

He who knows only his own side of the case, knows little of that. His reasons may be good, and no one may have been able to refute them. But if he is equally unable to refute the reasons on the opposite side; if he does not so much as know what they are, he has no ground for preferring either opinion. The rational position for him would be suspension of judgment, and unless he contents himself with that, he is either led by authority, or adopts, like the generality of the world, the side to which he feels most inclination. (p. 44)

It is the final phrase ('he is either led...most inclination') that is pertinent here. It refers back to his argument at the outset that his primary concern is with 'social' rather than 'political' oppression, and that liberty is at greater risk from the 'moral coercion of public opinion' because 'social tyranny [is] more formidable than many kinds of political oppression, since...it leaves fewer means of escape, penetrating much more deeply into the details of life, and enslaving the soul itself.' (10) But he proceeds as if this “'moral coercion' was simply an analogue of political oppression, emphasizing suppression by 'public opinion' as an external force rather in the way that a state might suppress dissent by simply eradicating dissidents. In Mill's terms, 
the 'enslavement' of the soul emerges as a result of individuals baulking at the consequences of pursuing a particular line of thought because of the social opprobrium they might face; it is a volitional act of withholding, out of self-interest or timidity, the expression of one's own opinions for fear of censure and/or persecution rather than the 'always-already' foreclosure of certain thoughts and ideas as described by Marxist theories of ideology and hegemony or Foucauldian notions of disciplinary power, for instance. Invoking the trope of openness, Mill later states that 'our merely social intolerance kills no one, roots out no opinions, but induces men to disguise them, or to abstain from any active effort for their diffusion.' (p. 39) Insofar as the 'social oppression' that Mill has in mind 'roots out no opinions', this implies that in the human mind all possible thoughts and ideas are always available, located presumably in a Platonic realm that is always open, awaiting capture by some brilliant mind that is nevertheless unable to express them openly. In other words, 'social oppression' is a form of 'intellectual pacification' in which

$[\ldots]$ the most active and inquiring intellects find it advisable to keep the general principles and grounds of their convictions within their own breasts, and attempt, in what they address to the public, to fit as much as they can of their own conclusions to premises which they have internally renounced.(p. 39)

'Moral coercion' is, therefore, a form of closure rather than foreclosure; even as the 'soul' is enslaved it nevertheless remains untouched, free to enquire about any and all subjects in private.

For this reason Mill is at pains to protect the autonomy of the individual's 'soul' from what he considers to be the 'evil' of social conformism even though such autonomy would seem to preclude his concern about the effectivity of social coercion 
in the first place. A few sentences before the passage quoted above, for instance, he begins with something a little dubious; having already stated that it is only in mathematics that 'all the argument is on one side', that even in natural philosophy there is a 'balance to be struck' between 'two contrasting opinions' and that this is all the more so in moral, religious, political and social discussion, it is difficult to see how one can only know one's own side of the case unless Mill is working here with an 'autochthonous' model of thought that denies the pressure of 'socialization' even as his concern with the threat of social coercion would appear to rest on it.

This insistence on a radical autonomy not only undermines the basis of Mill's own argument, but also reveals an aporia within which we might situate a critique of liberal free speech theory's apparent willingness to endorse receptivity. In pursuing his argument, Mill sunders the relationality of social communication on which his wider argument would appear to rest. The listener is no longer a part of a communicative transaction embedded in what Austin calls a 'total speech situation' (Austin and Urmson, 1973, p. 52), but rather an isolated, abstracted and disembodied receiver of an equally abstracted, discrete 'message'; it follows from this that the 'message', insofar as it is not materially related to any given receiver but in fact stands only in relation to any and all receivers, is more important than any individual listener/receiver. This has the effect of elevating 'speech' if not 'speakers' (who, like listeners, are equally subject to disembodiment and abstraction in this model insofar as they too are subject to the trope of openness which is Mill's key priority), which in turn rests on an idealist notion of 'thought and opinion'. In order for infinite and perpetual openness to be operative, in order, that is, for all speakers to be able to think all possible thoughts and all listeners to hear all possible opinions, actual, embodied and socially embedded communicative agents must withdraw and yield to 'speech', 
and it is significant that Mill states that all 'opinions' should be given a 'hearing', not all persons. Of course, Mill acknowledges that there can be no speech without persons; indeed, he explicitly states that speaking and writing are forms of action. That, however, is not the point; rather, the point is that conceptually speaking, in order to protect the radical autonomy of the individual on which his wider argument rests, and to enable the trope of infinite and perpetual openness that animates such autonomy and gives it the force he requires, Mill must emphasize 'speech' over and above speakers and listeners.

The consequences of this sundering and abstraction of communication operate in On Liberty in three particular ways. Firstly, there appears to be a disjuncture between speaking and listening. 'The sort of men' produced within a milieu of ‘intellectual pacification' are, says Mill, 'either mere conformers to commonplace, or time-servers for truth, whose arguments on all great subjects are meant for their hearers, and are not those which have convinced themselves.' (p. 39) Addressing oneself to one's 'hearers' is here placed in opposition to remaining to one's own convictions, but how does this relate to Mill's insistence on the necessity of listening to others? He had earlier argued that the only way to arrive at 'conviction' itself is to listen to all opinions that are necessary to come to a conclusion, but how is that possible unless those opinions are themselves directed towards 'hearers'? Mill's logic here would suggest that all such opinions are simply socially sanctioned substitutes for the 'truth' and not 'truth' itself. It is clear that in this passage 'addressing' oneself to one's 'hearers' is, for Mill, some kind of moral flaw - and this would in turn imply that one thinks independently of what one 'hears' since speech addressed towards 'hearers' is, by this logic, manifestly suspect, an example of 'intellectual pacification'. But if speaking with others in mind compromises one's intellectual sovereignty, what 
happens to 'listening'? Since one must listen to others, the act of listening must, on these terms, ipso facto compromise one's sovereignty. And if the goal, for Mill, is to protect that sovereignty at all costs, then this must in turn attenuate the value of 'listening'. In fact, it exposes it as nothing more than a rhetorical trope that plays handmaiden to the perpetual 'antagonism of opinions'. This requires 'listening' as a conceptual correlate but relegates its role to that of cipher, if that.

On the other hand, Mill writes somewhat later in the second chapter that [...] truth has no chance but in proportion as every side of it, every opinion which embodies any fraction of the truth, not only finds advocates, but is so advocated as to be listened to. (p. 60)

If the argument presented in the previous passage rested on a rupture between speech and listening, with each hived off into distinct domains that are implicitly hierarchized (listening is subordinate to speech), in this passage Mill suggests that listening is a function of speaking, that one is compelled to listen, as it were, by the 'force' of speech. This is, in fact, one of several passages in On Liberty, where the idea of 'compulsion' is deployed in a way that reveals a significant ambiguity in the way Mill uses this central concept. Compulsion is, for Mill, a cognate to 'coercion'. In a very early passage, he writes that 'social tyranny' is just as oppressive as 'political oppression' because it 'compel[s] all characters to fashion themselves upon the model of its [society's] own.' (p. 11) Somewhat later, he argues that

The object of this Essay is to assert one very simple principle, as entitled to govern absolutely the dealings of society with the individual in the way of compulsion and control $[\ldots .].[$ and $]$ as soon as mankind have attained the capacity of being guided to 
their own improvement by conviction or persuasion $[\ldots]$ compulsion $[\ldots]$ is no longer admissible as a means to their own good. (p.17)

But when he says truth must be 'so advocated as to be listened to,' 'compulsion' acquires a very different, positive inflection. It is a correlate and consequence of a certain inherent power and force in speech itself, or more precisely, speech that 'embodies any fraction of the truth'. Not only does 'compulsion' here destabilize the central category of his entire argument (moral coercion) but so too does it suggest that all agency rests with speaking. Listening is rendered passive, subject to the force of (truthful) speech, which is at odds with the apparently foundational status Mill ascribes to it elsewhere. Only if people speak up for their truth will people listen - but will they? What if they refuse to listen, as Polemarchus does in Plato's Republic? As Bickford notes, his refusal to listen is itself a deployment of power, and therefore contains within it some agency. The agency of listening is distinct from that of speaking even if, both conceptually and practically speaking listening and speaking cannot be said to operate in separate domains; it cannot be assumed, therefore, that one is simply an adjunct of the other.

Nor can it be assumed that to listen is to acquiesce to or simply absorb the power of 'speech' as Mill would seem to imply. It is not just in this passage that Mill renders listening a passive adjunct to 'active' speech. John Durham Peters has noted that the disjunction between 'speaking' and 'listening' appears to be structurally necessary to Mill's wider argument, although he does not notice that one is subordinated to the other, '[c]itizens are supposed to listen with ice and speak from fire. Our ears are supposed to be catholic, capable of accommodating many doctrines, but our voices are supposed to be firmly convinced in what we passionately believe to be true.' (Peters 2005, loc p. 1844, p.1846, p. 1890) With the key trope of infinite and 
perpetual openness in mind, this tension is the engine that keeps the 'anatagonism of opinions' in perpetual motion. Peters then pertinently asks:

[...] do the arguers ever become hearers? Don't they also have an obligation to hear the arguments of others who passionately believe otherwise? And if they do, then don't they risk turning from passionate believers to judicious teachers? Won't the general tendency of reflective listening be to create a society of rational weighers? Mill certainly hopes so... (p. 1858)

But if this is the case, if all those who hold passionate convictions and are dogmatically convinced of their rightness become, in the process, sober, tolerant and rational judges who impartially assess competing ideas with cool disinterestedness, then something like moral and intellectual entropy would result and the heat of battle would die out: the perpetual motion of the 'anatagonism of opinions' would come to a halt. This presumably would result in the very conformity that Mill fears. Therefore, whilst he may hope that the 'antagonism of opinions' produces a society of 'rational weighers' and sober judges of opinion, Mill also needs his own process to fail in order to prevent the closure of infinite openness. As Peters wryly observes, Mill needs dogmatic 'outlaws' to 'keep the disciplinary machine running.' (p. 1869) But this can only happen if those who speak passionately and with dogmatic conviction and those who listen with dispassionate and rational cool do not occupy the same circuit of communication. ' $[\mathrm{I}] \mathrm{t}$ is not on the impassioned partisan, it is on the calmer and more disinterested bystander, that this collision of opinions works its salutary effect,' writes Mill; in other words, the 'bystander' who listens stands outside the arena of battle and is not a participant within it. 
In Mill's communicative model, therefore, speakers and listeners are not identical to each other: speakers do not necessarily listen, and listeners do not speak at least until they have listened to all opinions and come to a conclusion (which, presumably, is never). And yet, much - indeed, everything - rests on this misalignment, the implications of which are quite profound. The speaking subject is privileged as the active agency that brings about the general but passive enlightenment of others. The listening self is not accorded that privilege of agency, and is thus relegated to a subordinate position in an asymmetrical relation of power even though it appears, on the face of it, that Mill's concern is precisely with this listening self. To all intents and purposes, then, speaking/writing and listening/reading must forever remain separate and distinct activities apparently unrelated to each other, whilst one is also, paradoxically, always subordinate to the other.

\section{II}

The rupture between speaking and listening, between the producer of discourse and its recipient, is accompanied by a telling slippage in Mill's lexicon between 'hearing' and 'listening'. Although Mill uses these terms interchangeably, they are, in fact, distinct - and Mill deploys them in ways that underline their distinction. He chiefly uses 'hearing' with reference to ideas and opinions: 'to refuse a hearing to an opinion' (p. 24); “'the only way in which a human being can make some approach to knowing the whole of a subject, is by hearing what can be said about it' (p. 27, my emphasis); 'denying a hearing to opinions' (p. 30); 'the dissentients have something worth hearing' (p. 56, my emphasis) etc. Sometimes, he deploys the term as a noun 
rather than verb, in the sense of 'a hearing' with all the judicial connotations it is meant to convey, such as 'opinions contrary to those commonly received can only obtain a hearing' (p. 62) or 'if they obtain a hearing at all' (p. 134). Nevertheless, in every instance, 'hearing' is related to 'opinions'. With 'listen' or 'listening', which cannot be translated into a noun, Mill signifies a practice, such as 'it has been his practice to listen to all that could be said against him' (p.27); '[he] listens patiently to a "devil's advocate"' (p. 28); 'when people are forced to listen to both sides' (p. 60) and so on.

What is the significance of this? Following Benjamin Barber, Susan Bickford (1996, p. 13) notes that the values of 'civility, empathy and respect [...] find expression in listening.' For Barber (cited in Bickford 1996, p. 13), '-Listening is a mutualistic art that by its very practice enhances equality' and goes beyond 'toleration of another's utterance' because it involves the exercise of an empathetic as well as sympathetic imagination that 'will put myself in his [the speaking other's] place, [and] will try to understand.' This emphasis on listening can be read against the way Mill de-privileges listeners and thereby reduces the practice of listening to secondary status in relation to an abstracted notion of 'speech' that itself appears merely to be a vehicle for 'ideas' and 'opinions'. So, it could be argued that despite using both 'listening' and 'hearing' Mill gives greater weight to the latter.

Moreover, 'hearing' is to 'listening' what space is to place; it is mere sensation in which the values attributed to listening by Barber and Bickford are absent. As such 'hearing' is a neutral, 'empty' category that is inert until animated or substantiated by an ethical investment in the other's speech or text through a practice of listening that pays attention to what is said - and who says it. Drawing on the phenomenology of 
perception developed by Merleau-Ponty, Bickford argues that 'listening has the same structure of perception as does vision' and therefore Merleau-Ponty's 'object-horizon' or 'figure-ground' theorization of visual perception is equally applicable to auditory perception. For Merleau-Ponty, 'objects appear when we concentrate or focus on them, and the surrounding world becomes the background or horizon that allows that object to stand out.' (Bickford, 1996, p. 22) However, existence is full not only of objects, but of other people. And precisely because my perception shows me my own perspectivity, it points to the perspective of those others [...] other people reflect our own way of taking up the world and require from us a particular kind of attention.' (p. 23) Therefore, 'in listening I must actively be with others. Listening as an act of concentration means that for the moment I make myself the background, the horizon, and the speaker the figure I concentrate on.' (ibid) 'Listening', therefore, is distinguished from 'hearing' by a certain quality of attentiveness that speaks of a particular kind of attitude towards, and therefore relationship with, the speaking 'other'; it involves a 'tuning in' or 'focussing' that 'hearing' does not. This characterization of listening not only foregrounds practice, it also therefore requires and depends upon a social relationality between 'speaker' and 'listener' that Mill abjures, albeit surreptitiously.

To give something or someone a 'hearing', then, does not presuppose the kind of attentiveness to others that characterizes 'listening'. Rather, as the judicial connotations suggest, it signals a proceduralism that is characteristic of liberal thought in general. As Stanley Fish (1994, p. 16) notes,

Liberal thought begins in the acknowledgment that faction, difference, and point of view are irreducible; but the liberal strategy is to devise (or attempt to devise) 
procedural mechanisms that are neutral with respect to point of view and therefore can serve to frame partisan debates in a nonpartisan manner..

Although Mill's 'battlefield of ideas' - which is far from procedurally neutral pre-dates the concept of the 'marketplace of ideas' (perhaps the most prevalent free speech metaphor of our time), the idea that all ideas and opinions should be given a 'hearing' is nevertheless present in the later metaphor, as it is also in the contemporary liberal emphasis on the virtues of 'cacophony' in the public sphere, a public sphere that is crowded, noisy and argumentative, in which all 'voices' can have their say. The assumption behind these tropes of 'marketplace' and 'cacophony' seems to be that a formally neutral public arena in which all voices and all kinds of speech can enter and from which none are excluded reproduces the conditions necessary to deliver Mill's theorization of free speech. The 'marketplace of ideas', for instance, 'is supposed to regulate in a purely formal way the contest between conflicting agendas' (Fish, 1994, p. 16) by enabling listeners, like shoppers in actual markets, to sample the wares and collectively 'winnow out' truth from falsehood in much the same way that Adam Smith suggests the 'invisible hand' of supply and demand will deliver a 'true' price. The key thing is to make sure each and every voice, opinion, argument is given a 'hearing' so that listeners/consumers will be able to make an informed choice; if this procedure is followed then the 'truth' will out.

And yet, even if it is possible to 'hear' all these - ideally limitless - voices, is it possible to listen to all of them, to give each the sustained attentiveness that distinguishes 'listening' from 'hearing'? And if that is the case, what happens to Mill's arguments for truth and therefore for the consequential benefit to 'mankind' of absolute liberty of thought, opinion and expression? Moreover, contrary opinions may abound in the public sphere or elsewhere, but one may not be able to hear them, never 
mind listen to them, because they constitute an alternative discourse or 'language game'. One may have as much freedom as one likes, but this may not induce the kind of truth sharpening that Mill and his followers advocate because one effect of such foreclosures is precisely to make it appear that one has tested the truth of one's opinions against all 'legitimate' arguments and as a result simply be deaf to alternative arguments or discourses that not do not make sense within the language game or universe of discourse one is situated in. ${ }^{1}$ Secondly, one may not hear others because they are subordinated and 'other' and their arguments are therefore silenced as a consequence of their subordination; this often intersects with the previous point insofar as these others are often excluded from the universe of discourse of those who are included. This incommensurability is not a function of liberty (or its lack) at all, but of difference and power. Thus, listening is both inflected and limited by the hierarchies of social power - the opinions of socially subordinate groups and persons are not listened to because they cannot be heard, either because they are excluded from or marginalized within social discourse (from the 'marketplace of ideas'), or because what they say is not intelligible to those with the privilege and authority to speak. By the same token, those voices that usually are heard and thereby listened to are usually those which are authorized and dominant within the normative frames of social discourse. ${ }^{2}$ As a result, the discursively privileged can imagine they are listening when, in fact, they are not.

Liberalism is notoriously blind to these inequalities and exclusions operating deep within its own conceptions of 'freedom'. This is as true of Mill and his contemporaries as it is of those more recent liberals who have invested such faith in the 'marketplace of ideas' and the 'cacophonous' public sphere. It is significant that when Mill elaborates what 'hearing' or 'listening' to conflicting opinions involves, 
for example, he evokes the judicial connotations of 'fairness' and 'impartiality' but, at the same time, is at pains to point out how very difficult if not impossible it is to do the very thing he argues is necessary. Thus, on the one hand, he argues that discovering 'that part of the truth that turns the scale [...] and decides the judgment of a completely informed mind' requires attention 'equally and impartially to both sides' of the argument (p. 44); on the other hand, it is precisely because 'very few have minds sufficiently capacious and impartial' (p. 55) to undertake this task that 'the interests of truth require a diversity of opinions' (p. 59). It appears contradictory to suggest that the purpose of 'diversity of opinion' is to enable each individual to come to a judgment of the truth by 'equally and impartially' attending to all sides of an argument, on the one hand, and to suggest, on the other, that such diversity is in fact required because of the inevitable failure of individuals to do precisely what Mill exhorts them to do. The latter leads him to admit that 'the tendency of all opinions to become sectarian is not cured by the freest discussion' (p. 60) whereas the former inspires him to suggest that such discussion will lead to the progressive moral development of 'mankind' and inevitably lead to an increasing 'number of doctrines which are no longer disputed or doubted' (p. 51) - that is, to consensus.

It is here that the full force and significance of the 'minoritarian' trope in Mill's argument becomes visible. This trope, which is manifest in perhaps the most famous and oft-quoted line in the whole essay - 'If all mankind minus one, were of one opinion, and only one person were of the contrary opinion, mankind would be no more justified in silencing that one person, than he, if he had the power, would be justified in silencing mankind' (p. 23) - appears in various guises (including the sentence just discussed concerning impartiality). ${ }^{3}$ This trope seems not only to be oriented toward conceptually defending 'individuality' and 'eccentricity' against 
conformism and 'moral coercion', but also suggests that liberty as such is really only the provenance of a handful of truly exceptional individuals through whom the benefits of progressive development can be generally diffused. For Mill the consequentialist, liberty is thus a means through which this goal can be achieved, and it is a means, moreover, that is given to the few not the many. As Domenico Losurdo's extensive critical examination of a wide range of liberal thinkers and writers from eighteenth and nineteenth-century France, England and the United States demonstrates, such liberal paternalism was not confined to Mill but was - and is $-\mathrm{a}$ general characteristic of liberal thought in general (Losurdo 2011).

This elitism not only animates Mill's antipathy to 'mass society' (perhaps the single most important impulse guiding the content and form of the essay), as well as his declared relish for 'genius' and evident, albeit ambivalent, nostalgia for times past when great and heroic deeds could be pursued by 'energetic' individuals in possession of a liberty he saw as being threatened by the moral and intellectual enervation of his own more democratically-inclined times $;{ }^{4}$ it also illuminates a rather curious passage where Mill admits that the logical conclusion of his arguments would tend toward a general entropy in which freedom of thought and 'diversity of opinion' would inevitably decrease:

As mankind improve, the number of doctrines which are no longer disputed or doubted will be constantly on the increase: and the well-being of mankind may almost be measured by the number and gravity of the truths which have reached the point of being uncontested [...] But though this gradual narrowing of the bounds of diversity of opinion is necessary in both senses of the term, being at once inevitable and indispensable, we are not therefore obliged to conclude that all its consequences must be beneficial. The loss of so important an aid to the intelligent and living 
apprehension of a truth, as is afforded by the necessity of explaining it to, or defending it against, opponents, though not sufficient to outweigh, is no trifling drawback from, the benefit of its universal recognition. Where this advantage can no longer be had, I confess I should like to see the teachers of mankind endeavouring to provide a substitute for it; some contrivance for making the difficulties of the question as present to the learner's consciousness, as if they were pressed upon him by a dissentient champion, eager for his conversion. (p. 51)

Mill's outward confession that he would like to see some future 'contrivance' that keeps thought and discussion perpetually open occludes, in fact, a genuine confession that his argument will, in fact, lead not to greater liberty of thought and opinion but less. The very conformism against which he argues will, ironically, be the end result. Hence the need for 'some contrivance' concocted by the 'teachers' of mankind, which, firstly, suggests that the grounds of Mill's argument for freedom of expression - the search for truth - do not in fact support it; secondly it is, in effect, an admission that for Mill the process is more important that the product (i.e. truth). This is an uncomfortable thing for a self-declared utilitarian philosopher to admit, but it does signal the deep substratum of proceduralism to which liberal arguments for freedom of expression inevitably return. If this is the case for such a strong advocate of consequentialism as Mill, it is even more so in later liberal discourse. The 'marketplace of ideas' still retains some genealogical affiliations to Mill's consequentialism insofar as its function is, through some mysterious correlate to the economic laws of market competition, to winnow out false ideas. Later, a generation of anti-consequentialist philosophers led by John Rawls and Ronald Dworkin would specifically address the weaknesses and contradictions in Mill's consequentialist arguments and in so doing boost still further liberalism's attachment to procedure and 
process (Rawls, 2005; Dworkin 2000, 1996). This attachment is now fully manifested in the contemporary 'absolutist' arguments for freedom of expression that suggest the existence of a crowded and 'cacophonous' public sphere is of itself sufficient to validate and vouchsafe freedom of expression as a good-in-itself (that is, unrelated to any good consequences that might arise from it) (Mondal, 2014).

According to this contemporary view, freedom of expression is entirely procedural: it consists simply in enabling all voices to speak and be given a 'hearing' in the public space. It does not matter what the effects of such speech are on those who listen to it - that is their concern. As with Mill, this clearly privileges speech and diminishes reception because, as I have already argued, this short-circuiting of the communicative transaction between speakers and listeners creates an asymmetry in which all agency is invested in speech and all responsibility rests on the shoulders of those who listen. In the case of speech, it is a case of power without responsibility insofar as the removal of accountability absolves 'speakers' of any obligation, in turn, to listen. Insofar as those who do speak are invariably those with the most powerful, dominant and authorized 'voices' - despite protestations to the contrary by liberal theoreticians - this induces both closures and foreclosures on their ability as well as willingness to listen and respond to the voices of 'others' who are marginalized, muted, silenced or not even recognized as legitimate 'speakers' at all. Paradoxically, this proceduralism also neutralizes the 'listener' or 'reader' by overwhelming them with all responsibility for the outcome of the communicative transaction for just as this model assumes speakers with power but no responsibility, so too does it assume listeners and readers who assume responsibility but no power: the reader/listener has no recourse to the speaker because the speaker has ceded all responsibility to the listener. The misalignment between 'speakers' and 'listeners' evident in Mill's On 
Liberty persists but its effects are amplified precisely because process is all. There is no longer any point or purpose to facilitating "diversity of opinion", as Mill would have it; rather, facilitating diversity is itself the point.

Ethically and politically speaking, liberal free speech theory turns the loss of control inherent in the act of speaking to the speaker's advantage. Every author knows - or should know - that the very process of disseminating their words involves erasure of their authority over the meaning of the text because the act of communication presupposes an 'addressee', an interlocutor, who 'takes' control of what is given - the gift of 'speech', as it were - in the act of listening or reading and engaging in the practice of interpretation. In so doing they assume 'responsibility' for the meaning. And yet, as I have argued elsewhere, neither power nor responsibility is wholly transferred from the one to the other; the 'text' of the communication - the speech - lies in-between the author/speaker and the reader/listener and both must assume a shared responsibility for it (Mondal, 2014, chapter 3). The 'text' invites mutual recognition because it is itself 'intersubjective'; more precisely, the text constitutes intersubjectivity because it is itself simultaneously constituted by both the act of speaking/writing and of listening/reading. Liberal free speech theory, indeed liberalism in general, with its assumption of individual sovereignty and investment in radical autonomy, finds it difficult if not impossible to account for intersubjectivity, for that which Levinas suggests lies entre-nous, between-us, which is the space of ethics (cited in Gibson 1999, p. 31). By insisting that the speaker cedes all responsibility and control to the listener, liberal free speech theory does not dwell in or upon the relational space of intersubjectivity but rather on the disjunctures between discrete acts of speaking and listening. The consequences of this are that speakers are assumed to be indifferent to the consequences of what they say, and listeners are 
paradoxically rendered impotent by assuming all power and responsibility for the outcome of communication.

This is why liberals applaud protests against 'offensive' speech that simply register disagreement or disapproval without actually attempting to enact any change in the discursive regime within which such speech is produced; that is, they applaud those protests that do not try to effect a political response to speech because such responses validate the pre-eminence of speech and the concomitant abjection of listening in liberal free speech theory. On the other hand, this is also why liberals are scandalized by 'censorious' protests that paradoxically mobilize free speech in order to limit it, because these responses refuse to reduce the responsibility of reception to an alibi for the impunities of speech. To engage in political struggle over the limits of speech is to assert the power of the listener to not just take responsibility but also to respond politically by using speech in a way that contests and challenges the unwarranted pre-eminence of 'speech'. This is not to suggest that all such responses are, in themselves, ethical or constitute a form of ethical responsiveness. Nevertheless, since the possibility of such an ethics and politics of 'listening' is precluded by liberalism's insistence on 'speech' and 'voice' the first, urgent task is to conceive models of communication and social relationality that push beyond the liberal frame.

\section{References}

Austin, J. L., and J. O. Urmson. 1973. How to do things with words. The William James Lectures delivered at Harvard University in 1955. (Edited by J. O. Urmson. Reprint.). New York: Oxford University Press. 
Bickford, Susan. 1996. The Dissonance of Democracy: Listening, conflict, and citizenship. Ithaca, N.Y.: Cornell University Press.

Dworkin, Ronald. 1996. Freedom's Law: The moral reading of the American Constitution. Oxford : Oxford University Press.

Dworkin, Ronald. 2000. Sovereign Virtue: The theory and practice of equality: Cambridge, MA ; London : Harvard University Press.

Fish, Stanley Eugene. 1994. There's no such thing as free speech, and it's a good thing, too. New York ; Oxford: Oxford University Press.

Gibson, Andrew. 1999. Postmodernity, Ethics, and the Novel. London : Routledge.

Losurdo, Domenico. 2011. Liberalism: A counter-history. London: Verso.

Mill, John S. 1859 [2011]. On Liberty. In: Kindle edition.

Mondal, Anshuman A. 2014. Islam and Controversy: The politics of free speech after Rushdie. Basingstoke: Palgrave.

Peters, John Durham. 2005. Courting the Abyss: Free speech and liberal tradition. Kindle ed. Chicago, Ill. ; London: University of Chicago Press.

Rawls, John. 2005. A Theory of Justice. Cambridge, Mass.; London: Belknap Press of Harvard University Press.

Spivak, Gayatri Chakravorty. 1988. 'Can the subaltern speak?' In Marxism and the Interpretation of Culture, edited by Lawrence Grossberg and Cary Nelson, 271311. Urbana: University of Illinois Press. 
${ }^{1}$ This, for example, is the implication of Gayatri Chakraborty Spivak's (in)famous essay 'Can the Subaltern Speak?' (Spivak, 1988) It is telling, however, that the essay emphasises speech over listening, which is a sign of the pre-eminence within even radical cultural politics of the former.

${ }^{2}$ On the impossibility of the 'marketplace of ideas' ever reproducing the trope of infinite and perpetual openness as theorized by Mill, that is, on its exclusions and foreclosures, see (Mondal 2014, chapter 2)

${ }^{3}$ Other examples include: 'there are few mental attributes more rare than that judicial faculty which can sit in intelligent judgment between two sides of a question' (p. 60); 'on any matter not selfevident, there are ninety-nine persons totally incapable of judging it for one who is capable' (p. 26); and 'Ninety-nine in a hundred of what are called educated men are in this condition' (p. 44).

${ }^{4}$ Alan Ryan, in his introduction to the Penguin edition, notes the unexpected but nevertheless clear proximity between Mill and Nietzsche despite their very different practical politics. 